\title{
PENERIMAAN MASYARAKAT TERHADAP PESAN KESEHATAN MELALUI MEDIA INTERNET
}

\author{
Wuri Rahmawati \\ Universitas 'Aisyiyah Yogyakarta \\ Jalan Ringroad Barat No.63, Yogyakarta 55592 \\ Email:wurirahma_w@unisayogya.ac.id
}

\begin{abstract}
ABSTRAK
Tujuan penelitian ini yaitu menganalisis pesan apa yang sering diterima masyarakat melalui media sosial, menganalisis kepercayaan masyarakat terhadap pesan yang diterima dan mengetahui sikap masyarakat terhadap pesan yang diterima. Penelitian ini merupakan penelitian deskriptif, dengan metode kuantitatif. Sampel penelitian adalah masyarakat DIY. Hasil penelitian menunjukkan bahwa Whattsapp merupakan media sosial yang digunakan oleh mayoritas masyarakat yang memiliki bidang pekerjaan wiraswasta, pegawai kantoran, ibu rumah tangga dan pelajar atau mahasiswa. Sedangkan media sosial lain yang digunakan masyarakat yaitu Facebook, Line, Instagram dan Twitter. Setiap media sosial mempunyai segmentasi pengguna yang berbeda-beda yang umumnya didasari faktor kebutuhan atau trend.Pesan yang diterima masyarakat melalui media sosial yang dimiliki antara lain mengenai gaya hidup, keagamaan, musibah, kesehatan, penawaran usaha dan penawaran kerja. Whattsapp menjadi media sosial yang menempati peringkat pertama sebagai penyampai pesan kepada masyarakat dengan bidang pekerjaan wiraswasta,pekerja kantoran, ibu rumah tangga dan pelajar atau mahasiswa. Tingkat kepercayaan masyarakat terhadap pesan kesehatan berbeda-beda. Masyarakat yang berwiraswasta memiliki tingkat kepercayaan tertinggi atas pesan kesehatan yang diterima. Sikap masyarakat terhadap pesan kesehatan secara mayoritas adalah kadang-kadang mengikuti dan meneruskan pesan. Penerimaan masyarakat terhadap pesan kesehatan melalui media sosial sebagian besar termasuk pada kelompok negotiated position dan sebagian kecil termasuk pada kelompok dominant hegemony position.
\end{abstract}

Kata kunci : Penerimaan Pesan, Media sosial, Intensitas atau Frekuensi, Kepercayaan, Sikap

ABSTRACT

The purpose of this study is to analyze what messages are often received by the public through social media, to analyze public trust in the message received and to know the public attitudes toward the message received. This research is descriptive research, with quantitative method.The research sampling is people of Special Region of Yogyakarta. The results show that WhatsApp is a social media used by the majority of people who are self-employed, officers, housewives and students. While other social media used include Facebook, Line, Instagram and Twitter.Each social media has its own user segmentation which is generally based on the "need" factor or trend. Messages received by the peopleon social media are mostly about lifestyle, religion, disaster, health, business offerings and job offerings. WhatsApp became the social media that ranks first as a messenger to the public who are self-employed, office workers, housewives and students.The level of public trust in health messages varies. Entrepreneurs or self-employers have the highest level of trust in received health messages. The public attitudes toward health messages by the majority are sometimes following and forwarding the message. Public acceptance of health messages through social media is mostly included in the negotiated position, and some othersare included in the dominant hegemony position group.

Keywords: Message Receipt, Social Media, Intensity or Frequency, Trust, Attitude

\section{Pendahuluan}

Masyarakat (community) adalah

kelompok-kelompok orang yang menempati

sebuah wilayah (teritorial) tertentu, yang

hidup secara relatif lama, saling

berkomunikasi, memiliki simbol-simbol dan

aturan tertentu serta sistem hukum yang

mengontrol tindakan anggota masyarakat,

memiliki sistem stratifikasi, sadar sebagai

bagian dari anggota masyarakat tersebut serta relatif dapat menghidupi dirinya sendiri (Bungin,2014 :163). Dalam masyarakat terjadi proses interaksi baik antar pribadi baik secara interpersonal, kelompok maupun massa (khalayak). Interaksi sosial merupakan hubungan dinamis menyangkut hubungan antara orang perorangan, antara kelompokkelompok manusia,maupun antara orang perorangan dengan kelompok manusia (Soekanto, 2002:62). Interaksi sosial dalam 
masyarakat mengalami pergeseran seiring dengan perkembangan teknologi.

Perkembangan teknologi informasi dan komunikasi sangat pesat sehingga berbagai informasi, kejadian, situasi dan kondisi di wilayah lain bahkan di seluruh dunia dapat diakses luas oleh masyarakat dalam waktu yang bersamaan. Menurut Marshall McLuhan dalam Little John (1997), saat ini masyarakat hidup dalam lingkungan global (global village) yaitu berjuta-juta orang di seluruh dunia dapat saling berkomunikasi dengan menggunakan media. Tidak ada batasan ruang dan waktu untuk saling berkomunikasi, bertukar informasi di era digital ini sebab masyarakat tidak harus bertatap muka atau berkunjung ke wilayah lain untuk mendapatkan informasi yang diperlukan. Internet memberikan akses informasi seluas-luasnya bagi masyarakat global di era digital ini.

Fenomena di masyarakat yang ada saat ini yaitu masyarakat sering menerima pesan-pesan yang berisi berbagai informasi yang kemudian akan diteruskan (forward) ke teman atau orang lain meski belum mengetahui secara pasti sumber dan kebenaran pesan yang diterima. Pesan viral yang belum pasti sumber dan kebenarannya tersebut sangat cepat tersebar di masyarakat. Kecepatan penyebaran pesan tersebut seiring dengan kemudahan akses internet di masyarakat. Internet merupakan media massa baru (new media) dalam masyarakat dengan karakteristik lebih individual, lebih beragam (diversified) dan lebih interaktif (Morissa,2015 :479).

Media baru yang mengalami pertumbuhan cukup pesat yaitu media sosial. Kehadiran media sosial telah menciptakan komunitas masyarakat maya yaitu komunitas masyarakat yang berinteraksi, membangun hubungan sosial budaya melalui dunia maya. Beberapa bentuk aktivitas masyarakat maya yaitu browsing, chatting dan searching.Interaksi masyarakat maya dapat terjadi melalui proses sosial disosiatif (persaingan,konflik, kompetisi) dan proses sosial asosiatif (kerjasama/cooperation, akomodasi dan asimilasi kebudayaan sehingga dapat mempengaruhi perilaku dan interaksi satu sama lain sesama masyarakat maya).

Data APJII tahun 2016 menunjukkanbahwa masyarakat pengguna internet paling banyak berusia 35-44 tahun yang masuk dalam kategori usia Ada sebagian masyarakat yang langsung mempercayai isi pesan tersebut namun ada juga sebagian masyarakat yang tidak mempercayainya.

Dalam teori penerimaan pesan menjelaskan bahwa ada 3 (tiga) posisi hipotekal ketika masyarakat melakukan decoding yaitu:

1. Dominant hegemony position,terjadi ketika setiap individu bertindak terhadap sebuah kode sesuai apa yang dirasakan mendominasi untuk memiliki kekuatan lebih pada kode lainnya. 
2. Negotiated position, khalayak mampu menerima ideologi yang dominan dan akan bergerak menindaklanjuti dengan beberapa pengecualian

3. Oppositional position,khalayak telah menerima dan telah mengerti namun khalayak memberi sandi bertolak belakang. Kondisi ini terjadi ketika khalayak memiliki sudut pandang kritis dalam menolak segala bentuk pesan yang disampaikan media dan memilih untuk mengartikannya sendiri.

Sedangkan apabila dilihat dari profesi pengguna tertinggi internet adalah masyarakat yang bekerja baik sebagai tenaga kerja maupun wiraswasta. Hal ini mengindikasikan bahwa kesibukan dalam dunia kerja mendorong masyarakat untuk memperoleh informasi dunia luar melalui internet.

Hal yang menarik bahwa ibu rumah tangga menempati urutan kedua setelah pekerja. Kondisi ini dapat memberikan informasi bahwa di sela-sela waktu kesibukan sebagai ibu rumah tangga, perempuan memperoleh informasi melalui internet salah satunya mengenai informasi kesehatan, yang menurut data 2016 menunjukkan bahwa 13,8\% pengguna internet mengakses informasi kesehatan.

Masyarakat dengan berbagai profesi tersebut memiliki pemaknaan yang berbedabeda terhadap pesan yang diterima. Ada yang masuk dalam kategori dominant hegemony position, negotiated position dan oppositional position. Menurut Oosgood dalam Littlejohn (1992: 133) bahwa individu-individu memberikan respon (stimulus) terhadap lingkungannya. Tiga tahapan dalam model perilaku yaitu encoding (menerima stimulus), association (stimulus dan respon) dan decoding (memaknai/menanggapi).

Sikap adalah kelompok-kelompok kepercayaan yang tersusun di sekitar objek perhatian yang mendorong seseorang untuk bentindak dan bertingkah laku menurut caracara tertentu terhadap objek tersebut (Morissan. 2015 :104-105). Sikap adalah perasaan mendukung atau memihak (favorable) maupun perasaan tidak mendukung atau tidak memihak (unfavorable) pada suatu objek atau informasi yang ada (Azwar,2016:5).

Pemaknaan terhadap berbagai informasi kesehatan melalui media sosial dapat beragam tergantung dari kepercayaan dan sikap pengguna atas setiap pesan yang diterima. Apabila memiliki tingkat kepercayaan yang tinggi masyarakat untuk mempercayai pesan dan kemudian mendorong untuk membagi pesan tersebut kepada orang lain. Sebaliknya apabila tingkat kepercayaan tehadap pesan rendah maka masyarakat akan menolak pesan tersebut dan tidak akan memberikan respon atas pesan yang diterima. Oleh karena itu, penelitian ini dilakukan untuk mengetahui penerimaan masyarakat terhadap informasi kesehatan melalui Internet. 


\section{Metode Penelitian}

Penelitian ini merupakan penelitian deskriptif dengan menggunakan metode kuantitatif yaitu menekankan pengumpulan informasi berdasar variable-variabel yang sudah tertentu dan mampu memberikan hasil yang diharapkan peneliti untuk melakukan generalisasi terhadap masalah yang dikaji (Sugiyono, 2010 :25). Variabel yang digunakan dalam kajian ini yaitu intensitas atau frekuensi, kepercayaan dan sikap. Sampel penelitian ini adalah masyarakat yang memiliki bidang pekerjaan wiraswasta, pegawai kantor, ibu rumah tangga dan pelajar atau mahasiswa. Pengumpulan data dengan melakukan wawancara terstrukur (kuesioner), observasi, pencatatan dan dokumentasi.

\section{HASIL PENELITIAN}

\section{A. Profil Masyarakat}

Profil masyarakat menggambarkan atau menginformasikan tentang jenis pekerjaan, umur dan kepemilikan media sosial berdasar jenis pekerjaan masyarakat di Daerah Istimewa Yogyakarta. terlihat bahwa jenis Hasil penelitian menunjukkan bahwa bidang pekerjaan masyarakat pengguna internet antara lain wiraswasta, pegawai kantoran (karyawan pabrik,satpam, tenaga pendidik guru dan dosen), ibu rumah tangga dan pelajar/mahasiswa.

Sedangkan umur masyarakat pada kisaran 19 tahun sampai dengan 45 tahun dari berbagai jenis pekerjaan tersebut, dengan rata- rata umur masyarakat pengguna layanan internet yaitu 32 tahun. Hal ini menunjukkan bahwa internet telah dinikmati oleh berbagai kalangan profesi maupun kelompok umur untuk berbagai kebutuhan. Bahkan internet saat ini telah menjadi kebutuhan bagi sebagian besar masyarakat Indonesia baik di perkotaan maupun pedesaan. Sebagaimana yang disampaikan oleh Marshall McLuhan dalam Little John (1997), bahwa saat ini masyarakat hidup dalam lingkungan global (global village) yaitu berjuta-juta orang di seluruh dunia dapat saling berkomunikasi dengan menggunakan media.

Media sosial yang paling banyak digunakan adalah Whattsapp (WA). Masyarakat pengguna Whattsapp di DIY sebesar 99,40\%, bahkan dari kelompok wiraswasta, pegawai kantoran dan ibu rumah tangga yang mempunyai handphone android atau smartphone $100 \%$ menggunakan Whattsapp. Media Instagram (IG) paling banyak digunakan oleh kelompok pelajar dan mahasiswa, Facebook (FB) paling banyak digunakan oleh kelompok ibu rumahtangga, Line paling banyak digunakan oleh pegawai kantoran, Twitter paling banyak digunakan oleh pelajar dan mahasiswa, serta media lainnya (BBM) banyak digunakan oleh pegawai kantoran

Sedangkan apabila dilihat dari kepemilikan media sosial (WA, IG, FB, Line, Twitter dan lainya) ternyata kelompok pegawai kantoran menempati urutan tertinggi 
sebagai pengguna seluruh media sosial tersebut dan sebaliknya kelompok ibu rumah tangga menempati urutan terendah. Kelompok ibu rumah tangga tidak memiliki media twitter dan media lain, artinya ibu rumah tangga hanya mengakses informasi melalui media sosial WA, IG, FB dan Line. Fakta tersebut menunjukkan bahwa setiap media mempunyai segmentasi pengguna yang berbeda-beda yang umumnya didasari faktor kebutuhan atau trend. Namun demikian hal ini perlu penelitian lebih lanjut agar mendapatkan informasi yang valid atas perilaku pengguna media sosial.

\section{B. Jenis Pesan dan Media Sosial yang digunakan masyarakat}

Pesan adalah suatu gagasan atau ide yang dituangkan dalam lambang-lambang disampaikan dengan cara tatap muka atau melalui media komunikasi, yang isinya dapat berupa ilmu pengetahuan,hiburan,informasi, nasehat atau propaganda. Jenis pesan yang diterima masyarakat sesuai dengan bidang pekerjaannya melalui media sosial yang dimiliki terlihat dalam tabel 1 berikut :

Tabel 1. Urutan atau Peringkat Jenis Pesan yang Diterima Masyarakat Sesuai dengan

Bidang Pekerjaannya melalui Media Sosial

\begin{tabular}{|l|l|l|l|}
\hline No & Pekerjaan & $\begin{array}{l}\text { Urutan / } \\
\text { Peringkat Pesan }\end{array}$ & $\begin{array}{l}\text { Urutan/Peringkat } \\
\text { Media Sosial }\end{array}$ \\
\hline 1 & Wiraswasta & Gaya Hidup & 1. Whattsapp \\
& & $\begin{array}{l}\text { Keagamaan } \\
\text { Musibah }\end{array}$ & 2. Line \\
& & $\begin{array}{l}\text { Kesehatan } \\
\text { Penawaran }\end{array}$ & \\
& & usaha & \\
& & Penawaran kerja & \\
\hline
\end{tabular}

\begin{tabular}{|c|c|c|c|}
\hline 2 & $\begin{array}{l}\text { Pegawai } \\
\text { Kantoran }\end{array}$ & $\begin{array}{l}\text { Keagamaan } \\
\text { Kesehatana } \\
\text { Musibah } \\
\text { Gaya hidup } \\
\text { Penawaran kerja } \\
\text { Penawaran } \\
\text { usaha }\end{array}$ & $\begin{array}{l}\text { 1. Whattsapp } \\
\text { 2. Facebook } \\
\text { 3. Instagram } \\
\text { 4. Line }\end{array}$ \\
\hline 3 & $\begin{array}{l}\text { Ibu Rumah } \\
\text { Tangga }\end{array}$ & $\begin{array}{l}\text { Keagamaan } \\
\text { Kesehatan } \\
\text { Gaya hidup } \\
\text { Penawaran } \\
\text { usaha } \\
\text { Musibah } \\
\text { Penawaran kerja }\end{array}$ & $\begin{array}{l}\text { 1. Whattsapp } \\
\text { 2. Facebook }\end{array}$ \\
\hline 4 & $\begin{array}{l}\text { Pelajar/ } \\
\text { Mahasiswa }\end{array}$ & $\begin{array}{l}\text { Keagamaan } \\
\text { Gaya hidup } \\
\text { Kesehatan } \\
\text { Musibah } \\
\text { Penawaran } \\
\text { usaha } \\
\text { Penawaran kerja }\end{array}$ & $\begin{array}{l}\text { 1. Whattsapp } \\
\text { 2. Line } \\
\text { 3. Facebook } \\
\text { 4. Instagram } \\
\text { 5. Twitter }\end{array}$ \\
\hline
\end{tabular}

Sumber : Data Primer Terolah, 2018

Berdasar tabel 1 terlihat bahwa urutan atau peringkat pesan dan jenis media sebagai sumber pesan untuk masing-masing bidang pekerjaan berbeda-beda. Pesan keagamaan menempati uturan pertama pada masyarakat yang memiliki bidang pekerjaan pegawai kantoran, ibu rumah tangga dan pelajar/mahasiswa sedangkan pesan gaya hidup menempati urutan pertama pada masyarakat yang memiliki bidang pekerjaan wiraswasta. Untuk pesan kesehatan ternyata menempati urutan kedua (2) pada masyarakat yang memiliki bidang pekerjaan pegawai kantoran dan Ibu rumah tangga, urutan ketiga (3) pada masyarakat yang memiliki bidang pekerjaan pelajar/mahasiswa serta urutan keempat (4) pada masyarakat yang memiliki bidang pekerjaan wiraswasta. Untuk pesan kesehatan menempati urutan kedua (2) pada masyarakat yang memiliki bidang pekerjaan pegawai kantoran dan ibu rumah tangga, 
urutan ketiga (3) pada masyarakat yang memiliki bidang pekerjaan pelajar atau mahasiswa dan urutan keempat (4) pada masyarakat yang memiliki bidang pekerjaan wirawsasta.

Sedangkan dari media yang menjadi sumber pesan bagi masyarakat, ternyata media sosial Whattsapp menempati urutan atau peringkat pertama pada semua bidang pekerjaan baik wiraswasta, pegawai kantoran, ibu rumah tangga maupun pelajar/mahasiswa. Facebook menempati urutan kedua (2) pada masyarakat yang memiliki bidang pekerjaan pegawai kantoran dan Ibu rumah tangga dan urutan ketiga (3) pada masyarakat yang memiliki bidang pekerjaan pelajar/ mahasiswa. Line menempati urutan kedua (2) pada masyarakat yang memiliki bidang pekerjaan wiraswasta dan pelajar/mahasiswa dan urutan keempat (4) pada masyarakat yang memiliki bidang pekerjaan pegawai kantoran. Instagram menempati urutan ketiga (3) pada pegawai kantoran dan urutan keempat (4) pada masyarakat yang memiliki bidang pekerjaan pelajar/mahasiswa.

Dari kondisi tersebut maka pesan keagamaan dan kesehatan hampir selalu menerpa masyarakat melalui media sosial yang dimiliki dan paling tinggi frekuensinya melalui media Whattsapp. Kondisi ini menunjukkan bahwa media sosial Whattsapp merupakan media sosial favorit bagi masyarakat luas karena berbagai layanan yang tersedia, kemudahan dalam mengakses dan mengoperasionalkan.

Oleh karena itu, pesan yang masuk melalui media khususnya pesan kesehatan hendaknya dapat dipertanggungjwabkan sumber dan kebenarannya sebab informasi kesehatan berkaitan dengan kondisi fisik dan mental bahkan menyangkut nyawa masyarakat. Apabila pesan kesehatan tidak jelas sumber maupun kebenarannya akan berdampak pada kebingungan, kekhawatiran dan ketakutan di masyarakat. Sebagai contoh pesan yang viral tentang ulat dalam sayuran kankung yang dapat tumbuh berkembang dalam perut. Pesan tersebut sangat berpengaruh terhadap pola pikir masyarakat tentang sayur kangkung yang selama ini sudah menjadi makanan konsumsi bagi diri dan keluarganya.

\section{Penerimaan Masyarakat terhadap pesan kesehatan melalui media sosial}

Masyarakat menerima pesan yang cukup beragam setiap hari dan salah satunya pesan mengenai kesehatan baik berkaitan dengan upaya promotif, preventif, kuratif, penyebab penyakit, makanan yang tidak sehat dikonsumsi, dan sebagainya. Penerimaan masyarakat atas pesan kesehatan yang diterima berbeda-beda bergantung pada proses decoding, intepretasi dan pemahaman inti (pemaknaan). Beberapa variabel yang digunakan untuk mengetahui penerimaan masyarakat terhadap pesan kesehatan yaitu intensitas atau frekuensi penerimaan pesan, 
tingkat kepercayaan dan sikap masyarakat terhadap pesan kesehatan yang diterima melalui media sosial. Adapun intensitas atau frekuensi penerimaan masyarakat mengenai pesan kesehatan melalui media sosial yang dimiliki cukup beragam, sebagaimana terlihat dalam tabel 2 berikut :

Tabel 2. Intensitas atau Frekuensi Pesan Kesehatan melalui Media Sosial yang Diterima Masyarakat

\begin{tabular}{|l|r|r|r|r|r|}
\hline Jenis Pekerjaan & Wiraswasta & $\begin{array}{l}\text { Pegawai } \\
\text { Kantoran }\end{array}$ & $\begin{array}{l}\text { lbu Rumah } \\
\text { Tangga }\end{array}$ & $\begin{array}{l}\text { Pelajar/ } \\
\text { Mahasiswa }\end{array}$ & Rata-Rata \\
\hline Kelalu (\%) & 11,11 & 0 & 0 & 4,55 & 3,91 \\
\hline Sering (\%) & 11,11 & 8,33 & 7,14 & 27,27 & 13,46 \\
\hline Kadang-kadang (\%) & 77,78 & 83,34 & 78,58 & 65,91 & 76,04 \\
\hline Tidak Pernah (\%) & 0 & 8,33 & 14,28 & 2,27 & 6,22 \\
\hline
\end{tabular}

Sumber : Data Primer Terolah, 2018

Berdasar tabel 2 di atas terlihat bahwa secara umum intensitas atau frekuensi masyarakat menerima informasi kesehatan melalui media sosial yang dimiliki tergolong pada kategori kadang-kadang yaitu sebesar $76,04 \%$, kemudian diikuti dengan kategori sering sebesar $13,46 \%$, kategori tidak pernah sebesar 6,22\% dan kategori selalu sebesar $3,91 \%$. Perbedaan intensitas atau frekuensi terpaan pesan dapat mempengaruhi masingmasing individu dalam memaknai atau mengartikan pesan yang diterima. Pemaknaan masing-masing individu tersebut akan mendorong penerimaan dan sikap masyarakat terhadap informasi kesehatan yang diterima baik yang sifatnya percaya maupun yang tidak percaya (menolak). Terdapat beberapa kriteria yang menjadi penyebab atau alasan masyarakat percaya dengan informasi kesehatan yang diterima antara lain sumber pesan yang jelas, masuk akal, sesuai pengalaman,sesuai referensi, menakutkan, panjang dan detail serta pesan singkat. Secara detail sebagaimana terlihat dalam tabel 3 berikut :

Tabel 3 Kriteria yang Menyebabkan Masyarakat Percaya terhadap Pesan Kesehatan yang Diterima melalui Media Sosial

\begin{tabular}{|c|c|c|c|c|c|}
\hline Karakteristik pesan & Wiraswasta & $\begin{array}{l}\text { Pegawai } \\
\text { Kantor }\end{array}$ & $\begin{array}{l}\text { Ibu Rumah } \\
\text { Tangga }\end{array}$ & $\begin{array}{l}\text { Pelajar/ } \\
\text { Mahasiswa }\end{array}$ & Rata-rata \\
\hline Sumber pesan jelas & 88,89 & 76,92 & 100 & 88,64 & 88,61 \\
\hline Masuk akal & 88,89 & 76,92 & 100 & 93,18 & 89,75 \\
\hline Sesuai pengalaman & 100 & 61,53 & 78,57 & 68,18 & 77,07 \\
\hline Sesuai referensi & 88,89 & 81,42 & 71,43 & 79,55 & 80,32 \\
\hline Menakutkan & 66,67 & 38,46 & 28,57 & 54,55 & 47,06 \\
\hline Panjang dan detail & 33,33 & 46,15 & 42,86 & 40,91 & 40,81 \\
\hline Pesan singkat & 22,22 & 15,38 & 14,28 & 20,45 & 18,08 \\
\hline Rata-rata & 69,84 & 56,68 & 62,24 & 63,64 & 63,10 \\
\hline
\end{tabular}

Sumber : Data Primer Terolah, 2018

Berdasar tabel 3 di atas terlihat bahwa secara berurutan dari kriteria yang paling besar berpengaruh terhadap kepercayaan masyarakat pada pesan kesehatan melalui pesan media sosial yaitu pesan atau informasi kesehatan yang kriterianya masuk akal (dapat diterima secara nalar),memiliki sumber pesan yang jelas, sesuai referensi dan sesuai pengalaman, pesan yang menakutkan, pesan panjang dan detail serta pesan yang singkat. Fakta ini menunjukkan bahwa sebagian besar masyarakat telah melakukan seleksi atas pesan atau informasi kesehatan yang diterima melalui media sosial. Hal ini karena kesehatan berkaitan dengan kepentingan individu dan berkaitan langsung dengan nyawa seseorang sehingga masyarakat lebih berhati-hati untuk mempercayai pesan yang diterima. 
Apabila dilihat dari jenis pekerjaan, terlihat bahwa masyarakat yang berwiraswasta memiliki tingkat kepercayaan tertinggi atas pesan kesehatan yang diterima, kemudian diikuti oleh pelajar atau mahasiswa, Ibu rumah tangga dan yang terakhir oleh pekerja kantoran. Hal ini terjadi seiring dengan intensitas atau frekuensi penerimaan masyarakat mengenai pesan kesehatan melalui media sosial yang dimiliki sebagaimana dalam tabel 3 yang menunjukkan bahwa masyarakat yang berwiraswasta mempunyai intensitas menerima pesan kesehatan dengan kategori selalu paling tinggi $(11,11 \%)$, kemudian pelajar/mahasiswa $(4,55 \%)$, ibu rumah tangga dan pegawai kantoran (0\%). Semakin tinggi intensitas atau frekuensi masyarakat terpapar pesan kesehatan melalui media berpengaruh terhadap tingkat kepercayaan masyarakat terhadap pesan yang diterima.

$$
\text { Tingkat kepercayaan dapat }
$$
mempengaruhi sikap atau tindakan masyarakat atas pesan kesehatan tersebut. Sikap atau tindakam tersebut dapat berupa menjalankan sebagaimana isi pesan dan atau meneruskan pesan kesehatan tersebut kepada orang lain baik melalui jaringan pribadi (Japri) maupun melalui grup-grup yang dimiliki. Hasil penelitian menunjukkan bahwa mayoritas masyarakat memiliki sikap atau tindakan yang masuk pada kategori intensitas atau frekuensi kadang-kadang mengikuti $(75,43 \%)$ dan meneruskan $(75,40 \%)$ pesan kesehatan yang diterima melalui media internet. Pada kategori frekuensi kadangkadang ini, kelompok masyarakat yang memiliki bidang pekerjaan wiraswasta menempati peringkat tertinggi dalam mengikuti pesan kesehatan sedangkan kelompok masyarakat yang memiliki pekerjaan ibu rumah tangga menempati peringkat tertinggi dalam meneruskan pesan kesehatan.

Terdapat $12,36 \%$ masyarakat yang tidak pernah meneruskan atau mengikuti pesan kesehatan yang diterima melalui media internet yang dimiliki. Pegawai kantoran menempati peringkat tertinggi tidak pernah mengikuti pesan kesehatan, dan ibu rumah tangga menempati peringkat teertinggi tidak pernah meneruskan pesan kesehatan. Untuk kategori frekuensi sering, terdapat 8,82\% masyarakat yang mengikuti pesan dan 9,94\% masyarakat yang meneruskan pesan. Pelajar atau mahasiswa menempati peringkat tertinggi sering mengikuti dan meneruskan pesan kesehatan yang diterima. Sedangkan kategori frekuensi selalu terdapat $7,76 \%$ masyarakat yang mengikuti pesan dan 2,27\% masyarakat yang meneruskan pesan. Pegawai kantoran menempati peringkat tertinggi yang selalu mengikuti pesan kesehatan, sedangkan pelajar atau mahasiswa yang selalu meneruskan pesan kesehatan.

Sikap berkaitan dengan tingkat kepercayaan masyarakat terhadap pesan yang diterima sebagimana terlihat dalam penjelasan 
sebelumnya pada tabel 4 Di samping itu ternyata dalam penelitian ini juga ditemukan bahwa sikap mengikuti atau meneruskan pesan kesehatan berkaitan dengan jenis pekerjaan masyarakat. Oleh karena itu perlu kajian lebih lanjut untuk dapat memperoleh penjelasan yang akurat mengenai sikap masyarakat terhadap pesan kesehatan berdasar jenis pekerjaan yang dimiliki.

Berdasar uraian tentang intensitas atau frekuensi, tingkat kepercayaan dan sikap masyarakat terhadap pesan kesehatan yang diterima melalui media sosial maka menurut teori penerimaan, mayoritas masyarakat mampu menerima isi pesan kesehatan yang dominan dan akan bergerak menindaklanjuti dengan beberapa pengecualian (negotiated position). Artinya masyarakat menerima pesan dan akan mengikuti ataupun meneruskan pesan kepada orang lain jika masyarakat mempunyai kepercayaan atas kebenaran pesan tersebut. Apabila masyarakat kurang atau tidak percaya terhadap pesan tersebut maka pesan tidak akan diikuti ataupun diteruskan kepada orang lain. Kondisi ini menunjukkan bahwa mayoritas masyarakat telah melakukan seleksi atas pesan kesehatan yang diterima sehingga tidak semua pesan yang diterima dipercayai, diikuti dan diteruskan. Namun masih ada masyarakat yang belum melakukan seleksi atas pesan kesehatan yang diterima, sehingga selalu mengikuti atau meneruskan pesan tersebut (dominant hegemony position), meski jumlahnya lebih sedikit dari negotiated position. Sehingga upaya literasi media penting tetap dilakukan di era digital saat ini.

\section{KESIMPULAN}

Whattsapp merupakan media sosial yang digunakan oleh mayoritas masyarakat yang memiliki bidang pekerjaan wiraswasta, pegawai kantoran, ibu rumah tangga dan pelajar atau mahasiswa dan menempati peringkat pertama sebagai penyampai pesan kepada masyarakat. Sedangkan media sosial lain yang digunakan masyarakat yaitu Facebook, Line, Instagram dan Twitter. Setiap media sosial mempunyai segmentasi pengguna yang berbeda-beda yang umumnya didasari faktor kebutuhan atau trend.Adapun pesan yang diterima masyarakat melalui media sosial antara lain mengenai gaya hidup, keagamaan, musibah, kesehatan, penawaran usaha dan penawaran kerja.

Berdasarkan frekuensinya, pesan kesehatan menempati urutan kedua (2) pada masyarakat yang memiliki bidang pekerjaan pegawai kantoran dan Ibu rumah tangga, urutan ketiga (3) pada masyarakat yang memiliki bidang pekerjaan pelajar/mahasiswa serta urutan keempat (4) pada masyarakat yang memiliki bidang pekerjaan wiraswasta. Tingkat kepercayaan masyarakat pada pesan kesehatan melalui pesan media sosial dipengaruhi oleh pesan atau informasi kesehatan yang masuk akal (dapat diterima secara nalar),memiliki sumber pesan yang 
jelas, sesuai referensi dan sesuai pengalaman, pesan yang menakutkan, pesan panjang dan detail serta pesan yang singkat. Masyarakat yang berwiraswasta memiliki tingkat kepercayaan tertinggi atas pesan kesehatan yang diterima, kemudian diikuti oleh pelajar atau mahasiswa, Ibu rumah tangga dan yang terakhir oleh pekerja kantoran.

Sikap masyarakat terhadap pesan kesehatan secara mayoritas adalah kadang-kadang mengikuti dan meneruskan pesan tersebut, diikuti oleh sikap tidak pernah, sering dan terakhir selalu mengikuti maupun meneruskan pesan kesehatan yang diterima. Sikap mengikuti atau meneruskan pesan kesehatan selain karena frekuensi dan tingkat kepercayaan juga berkaitan dengan jenis pekerjaan masyarakat.

Penerimaan masyarakat terhadap pesan kesehatan melalui media sosial sebagian besar termasuk pada kelompok negotiated position dan sebagian kecil termasuk pada kelompok dominant hegemony position. Negotiated postiton menunjukkan mayoritas masyarakat telah melakukan seleksi atas pesan kesehatan yang diterima, sehingga akan mengikuti ataupun meneruskan pesan kepada orang lain jika masyarakat mempunyai kepercayaan atas kebenaran pesan tersebut. Dominant hegemony position menunjukkan sebagian kecil masyarakat belum melakukan seleksi atas pesan kesehatan yang diterima sehingga akan mengikuti dan atau meneruskan setiap pesan kesehatan tersebut tanpa mengetahui kebenarannya secara pasti.

\section{SARAN}

Perlu kajian lebih mendalam dengan menambahkan indikator tingkat pendidikan, faktor-faktor yang menyebabkan segementasi kepemilikan media sosial, pengaruh atau hubungan antara bidang pekerjaan dengan penerimaan masyarakat terhadap pesan kelsehatan melalui media sosial (internet). Perlu juga adanya program literasi media pada masyarakat agar bijak dalam bermedia sosial dan selektif terhadap pesan kesehatan yang diterima melalui media sosial yang dimiliki.

\section{DAFTAR PUSTAKA}

Azwar, Saifuddin. 2016. Sikap Manuasia : Teori dan Pengukurannya.Yogyakarta :Pustaka Pelajar

Bungin Burhan. 2014. Sosiologi Komunikasi : Teori,Paradigma dan Diskursus Teknologi Komunikasi di Masyarakat.Jakarta : Kencana Prenadamedia Group

Littlejohn.1992. Theories of Human Communication. Belmont California : Wadsworth Publishing Company

Morissan. 2015. Teori Komunikasi Individu hingga Massa. Jakarta :Prenadamedia Group 
Sugiyono. 2010. Statistika untuk Penelitian.

Bandung : CV Alfabeta

Artikel Seminar Nasional "Knowledge

Community Developing" COMICOS

UAJY 8 September 2018
Artikel Workshop "Big Data is Methodology" Ilmu Komunikasi UMY 23 Juli 2018

Kompas.com. Whattsapp Terbanyak di Dunia. Edisi 17 November 2016. Pukul 06.15 WIB 